\title{
Alzahrawi: The Father of Surgery
}

Alzabrawi: el padre de la cirugía

\author{
Ali Alyammahi \\ Universidad de Córdoba
}

\section{Introduction}

Spain has been famous for scholars and scholars since ancient history, as it is the cradle of Andalusian Islamic civilization, and it has the first universities in the world. People used to come to seek knowledge and learn from scholars who are familiar with various sciences. In this article, we will travel with a character from Spain, and a world of its scholars, and we will talk about his upbringing, life, writings and why this character was chosen.

The emergence of European science during the Renaissance dates back to the flourishing of science during the Islamic Golden Age, as Muslim scholars translated and comprehended Greek works, adding their own comments to them, and thanks to their perceptual observations, experiences and skills, Muslim scholars, physicians and philosophers in Seville, including Al-Zahrawi or Albucasis (936-1013), Ibn Zahr or Avenswar (1092-1162), and Ibn Rushd or Ibn Rushd (1126-1198) were the most influential physicians in the Western lands.

According to Chavoushi, Ghabili, Kazemi, Aslanabadi, Babapour, Ahmedli and Golzari, E. (2012). Abul Qasim Khalaf 
ibn al-Abbas al-Zahrawi, known as Abulcasis or Albucasis in the West, was conceived in al-Zahra (close to Cordoba, Spain) in 936 a. D. He sprang from the Ansar clan of Medina, Saudi Arabia, who had settled before in Spain. He lived the greater part of his life in Cordoba where he contemplated, instructed, and rehearsed medication and medical procedure. Also, Al-Zahrawi got one of the most renowned specialists of the Muslim time and was doctor to Abd al-Rahman III (912-961) and his child Al-Hakam II (915-976) of Spain, the Umayyad Caliphs of Cordoba. In contrast to his notable distributed work, a couple subtleties stay about Al-Zahrawi's life. Al-Zahrawi was first referenced by the Andalusian researcher, Abu Muhammad ibn Hazm (993-1064), as one of the extraordinary doctor specialists of the Moorish Spain. The main known memoir of Al-Zahrawi was outlined in Al-Humaydi's Jadhwat al-Muqtabis fi Dhikri Volat al-Andalus (On Andalusian Savants) gathered sixty years after Al-Zahrawi's passing. After almost fifty years of clinical vocation full with extraordinary unique commitments especially in the court of Caliph, Al-Zahrawi passed on in 1013 a. D.

Abu al-Qasim al-Zahrawi or what the West knows as Albuccasis or Zahravius is Abu Qasim Khalaf Ibn Abbas al-Zahrawi, he was born in the city of Cordoba, the current capital of Spain (formerly Muslim Andalusia), specifically in the Zahra neighborhood, six miles northwest of Cordoba. And descended from Medina in the Arabian Peninsula, where his ancestors came with the Islamic armies that conquered Andalusia and they settled in.

A pioneer in all fields of surgical treatment, Al-Zahrawi advanced severa authentic strategies in addition to instruments. He posted the primary ever surgical encyclopaedia entitled «AtTashrif». His manner of questioning and exercise of surgical treatment stimulated many next brilliant surgeons. As a end 
result of his imperious paintings and contribution to surgical treatment, he has been given the identify of «Father of Surgery», and supplied but any other beacon of mild withinside the darkish ages. In his many papers and manuals, he describes diverse operations and tactics which had by no means been recorded before. Some have defined him because the first ever plastic surgeon, significantly for his interest to and techniques of incision, use of silk thread suture to acquire desirable cosmesis. He describes what's notion to be the primary strive at discount mammaplasty for the control of gynaecomastia. He offers distinct descriptions of different fundamental surgical strategies including cautery and wound control. The intention of this paper is to spotlight and remind us of the priceless contributions made with the aid of using this fantastic pioneer withinside the discipline of surgical treatment, that have acted a preamble for lots strategies and tactics used withinside the discipline of plastic surgical treatment.

He was the first to use cotton (in surgical dressings, to control bleeding and as a lining for casting fractures). He also was the first to use cauterization, wax, and alcohol to control skull hemorrhage during cranial surgery and to describe arterial ligament long before Ambrose Barry. Moreover, He was the first surgeon to describe an ectopic pregnancy and to establish lithotripsy for vaginal operations. Al-Zahrawi wrote the Description of tracheostomy operations and their use in emergency situations, and he wrote about orthodontics, how and how to treat deviated teeth. Another thing he discovered was the water on the brain known as hydrocephalus, he wrote a total of 30 paper volumes on medicine where he recommended ways to treat this condition.

For the remedy of hydrocephalic children, surgical evacuation of superficial intracranial fluid changed into first defined 
through the Muslim health care professional Abu al-Qasim Khalaf ibn al-Abbas Al-Zahrawi (936-1013 a. D.), the father of surgery, regarded within side the western scientific literature as Abulcasis or Albucasis. He lived and practiced surgical treatment and medicinal drug within side the metropolis of Al Zahra, the capital of al-Andalus within side the tenth century. As well as, He lived and practiced surgical treatment and medicinal drug in the metropolis of Al Zahra, the capital of al-Andalus within side the tenth century.

The ultimate and biggest quantity of At-Tasrîf named «On Surgery» changed into not anything much less than the best fulfillment of medieval surgical procedure. It changed into the primary impartial surgical treatise ever written in detail. It covered many photographs of surgical units, maximum invented through al-Zahrāwī himself, and reasons in their use. Al-Zahrāwī changed into the primary scientific creator to offer illustrations of units utilized in surgical procedure. His treatise of surgical procedure incorporates about 2 hundred such drawings starting from a tongue depressor and a teeth extractor to a catheter and an intricate obstetric device.

The kind of operations protected is amazing. Al-Zahrāwī mentioned bloodletting, midwifery and obstetrics, the remedy of wounds, the extraction of arrows and the putting of bones in easy and compound fractures. He additionally promoted using antiseptics in wounds and pores and skin accidents, and devised sutures from animal intestines, silk, wool and different substances. He defined the publicity and department of the temporal artery to alleviate positive forms of headaches, diversion of urine into the rectum, discount mammoplasty for excessively massive breasts, dental surgical procedure, and the extraction of cataracts. He wrote appreciably approximately accidents to bones 
and joints, even citing fractures of the nasal bones and of the vertebrae, in fact «Kocher's method» for lowering a dislocated shoulder changed into defined in At-Tasrif lengthy earlier than Kocher changed into born.

\section{Conclusion}

To conclude, Alzahrawi have made a major impact on the medical field and history which made his name popular among numerous other scientists. In this article we had a look at the important achievements Alzahrawi have done. 


\section{REFERENCIAS BIBLIOGRÁFICAS}

Amr, S. y Tbakhi, A. (2007). «Abu Al Qasim Al Zahrawi (Albucasis): Pioneer of modern surgery». Annals of Saudi Medicine, 27(3), p. 220.

Chavoushi, S. H., Ghabili, K., Kazemi, A., Aslanabadi, A., BABapour, S., Ahmedli, R. y Golzari, S. E. J. (2012). «Surgery for Gynecomastia in the Islamic Golden Age: Al-Tasrif of Al-Zahrawi (936-1013 a. D)». ISRN Surgery, pp. 1-5.

Elgohary, M. A. (2006). «Al Zahrawi: The father of modern surgery». Ann Ped Surg, 2(2), pp. 82-87.

Markatos, K., Mavrogenis, A., Brilakis, E., Korres, D., Karamanou, M. y Chronopoulos, E. (2019). «Abulcasis (9361013): his work and contribution to orthopaedics». International Orthopaedics, 43(9), pp. 2199-2203.

Turgut, M. (2008a). «Surgical scalpel used in the treatment of «infantile hydrocephalus» by Al Zahrawi (936-1013 a. D.)». Child's Nervous System, 25(9), pp. 1043-1044. 